\title{
通風環境における気持ちよさ評価モデルに関する実験的研究 風速がステップ変化した場合における検討 \\ EXPERIMENTAL STUDY ON EVALUATION MODEL OF PLEASANT SENSATION UNDER THE CROSS-VENTILATED ENVIRONMENT
}

Analysis under step-wisely changing wind velocity

森上伸也*，大場 正昭**

Shinya MORIKAMI and Masaaki OHBA

\begin{abstract}
The pleasantness by cross-ventilation can improve the comfort sensation of the residential environment. Cabanac defined "pleasant sensation" as a positive comfort against the comfort that is regarded as a lack of discomfort in steady state proposed by Gagge et al. The pleasant sensation index for the thermal environment is not established yet. In this study, the human-subjective experiments were conducted for step-wisely changing wind velocity by using climate-controllable wind tunnel. Through the experiment, the pleasant sensation was found to be transient and different from the thermal and comfort sensations. The pleasantness occurred when suddenly changing from the discomfort environment to neutral environment. The regression formula on the pleasantness was obtained from experimental results by using a mean skin temperature and a differential of mean skin temperature as the explanatory parameter.
\end{abstract}

Keywords : Cross-ventilated environment, Subjective experiment, Pleasant sensation, Thermal comfort 通風環境，主観申告実験，気持ちよさ，温熱快適性

\section{1.はじめに}

伝統的に日本の住宅では，自然通風が室内環境の改善に有効な手 段であると考えられてきた。近年ではパッシブハウスとして，通風 による冷房負荷削減効果についても着目されている 1)。しかし，気 象庁の練馬観測所における 2014 年 8 月の日平均気温は $31.6^{\circ} \mathrm{C}$, 最 高気温は $37.6^{\circ} \mathrm{C}$ を記録しており, 夏季における不適切な環境調整行 動や過剩な節電対策は, 熱中症患者数の増加を助長させる危険性が ある 2)。一方, 田辺ら ${ }^{3)}$ が行った寝室環境に関するアンケートで, エアコンの使用が好きかという質問に対して,「はい」と回答したの は $53 \%$ であた。「いいえ」と回答したうちの約半数は,「体調を崩 す」という理由であることがわかっており，エアコンの使用が必ず しも温熱快適性を向上させるとはいえない。室内温熱環境の質の低 下は健康, 居住性, 労働生産性に梁刻な影響を及ぼす。健康的な室 内温熱環境を構築するためには, 自然換気および通風の有効利用に ついてさらに検討する必要がある。

通風環境の温熱快適性を評価するには，様々な現象を取り扱う必 要がある。周囲環境の気温や相対湿度は，人体との熱交換に影響を 与え, 人体は周囲環境に合わせて, 温熱制御反応によって熱交換を 促進・抑制させることで，体温を一定に保つ ${ }^{4)}$ 。また，人はこれま での経験から, 周囲の温熱環境に対して,「暑い」や「涼しい」とい
った温冷感と,「快適」や「気持ちよい」という感覚を判断すること が可能である。温熱快適性を評価する上では，熱交換現象，人体温 熱生理モデルおよび主観申告モデルを包括する温熱評価モデルが必 要となる。

\section{2. 既往の研究}

\section{1 住宅の通風気流特性について}

下地ら，飯野ら 5), 6)が行った実験住宅における通風の実測による と, 通風の乱れの強さは空調風の約 2 倍あり, 通風は風速の変動が 大きいことがわかっている。筆者らがこの実測データをスペクトル 解析した結果，通風のスペクトルピーク周波数は $0.016 \mathrm{~Hz}$ で，空調 風が $0.258 \mathrm{~Hz}$ であった。通風は空調風よりも緩やかな変動特性が支 配的であるといえる。

赤林ら ${ }^{7)}$ は通風について地域，建物周囲および建物性能を考慮し た評価方法として CVDH(Cross Ventilation Degree Hour: 通風デグリ アワー)を提案し, 定常状態における通風による温熱環境改善効果の 有効性を検討している。

\section{2 室内の温熱快適性について}

温熱環境評価法は Fanger, Gagge らによって提案されている。 Fanger $^{8)}$ の PMV (Predicted Mean Vote: 予測温冷感申告) 指標は
* 豊田工業高等専門学校建築学科 助教・博士 (工学)

** 東京工芸大学 名誉教授. 工博
Assist. Prof., Dept. of Architecture, National Institute of Technology, Toyota College, Dr.Eng.

Emeritus Prof., Tokyo Polytechnic University, Dr.Eng. 
ISO77309) に採用されている。PMV は, 人体周りの熱バランスと温 冷感申告值を結びつけたものである。シンプルな算出方法と画期的 なアイデアであることから世界的に広く利用されている。PMV は執 務空間の温熱環境評価を目的としていることから，定常状態におけ る実験結果を基に求められており, 通風環境の温熱環境評価一適用 するのは難しい。

Gagge らの SET* (New Standard Effective Temperature: 標準新有効 温度 ${ }^{10}$ は人体温熱生理 2 node モデル ${ }^{11}$ を用いて算出される。SET* は, 相対湿度 $50 \%$, 風速 $0.1 \mathrm{~m} / \mathrm{s}$, 着衣量 $0.6 \mathrm{clo}$, 代謝量 $1.0 \mathrm{met}$ の標 準環境と対象の環境が，等価な温熱環境となるときの気温および平 均放射温度と定義されている。SET*は, 人体温熱制御反応を考慮し ているが, その算出過程から, 定常状態における温冷感指標であり, 自然通風環境の温熱快適性を評価するのは困難である。

桑沢ら ${ }^{12}$ は気流の乱れの強さと卓越周波数を変化させて, 変動風が 人体に与える物理量および心理量の効果について検討している。気流 の乱れの強さは, 対流熱伝達率に影響を及ぼすことが明らかにされてい る。また, 気流の卓越周波数は心理量に影響を及ぼすことを示している。 佐藤ら ${ }^{13)}$ は自然通風を模擬した環境条件における温熱快適性の連続 申告調査を行い, 自然通風のような変動風は, 暑熱環境でも心理的・ 生理的に許容可能な環境となり得ることを明らかにしているが，温 熱快適性の定量評価およびモデル化には至っていない。

小野間ら ${ }^{14)}$ は, 自然通風環境亡空調風環境における実測アンケー 卜調査を行っている。自然通風環境における「涼しさ」申告は, 断 続的に長い時間生じているのに対して, 空調風環境における「涼し さ」申告は, 実測中ほとんど申告されなかったことを報告している。 Cabanac ${ }^{15}$ は, Gagge ら ${ }^{16)}$ が提案する「不快を取り除いた状態である 消極的快適性 comfort」に対して,「積極的快適性 pleasant」を提案し ている。久野ら ${ }^{17}$ は, 温熱快適性分野における積極的快適性を 2 次 元温冷感モデルとして提案し, 非定常状態における温冷感を「涼し い」と「暖かい」としている。

\section{3. 本研究の目的}

自然通風環境における温熱快適性のメカニズムは, 風のゆらぎや 汗の泠却効果等が複合的に影響するので，未だ解明されていない。 通風気流環境下における温熱快適性を詳細に調べることで, 通風の 積極的利用および温熱環境評価法への活用が考えられる。

本研究では通風型人工気候室を用いて, 風速がステップ変化した 通風環境における主観申告実験を行い, 通風環境における気持ちよ さ評価と人体の生理量を関連付けた気持ちよさ評価の実験回帰モデ ルを提案することを目的とする。

\section{4. 通風型人工気候室と測定機器の概要}

\section{1 通風型人工気候室の概要}

通風型人工気候室 $\left.{ }^{18}\right)$ は, 自然風の変動と人体の生理的, 心理的反 応の関係を研究するために, 東京工芸大学風工学研究センターに 2009 年 11 月に設置された。図 1 に通風型人工気候室の概要を示す。 通風型人工気候室の外形は, 幅約 $5.0 \mathrm{~m}$, 長さ $12.6 \mathrm{~m}$, 高さ $3.0 \mathrm{~m}$ で, 測定室と前室の 2 室を有する。測定室は幅約 $3.7 \mathrm{~m}$, 長さ $8.0 \mathrm{~m}$, 高 さ $2.7 \mathrm{~m}$ で, 前室は幅 $3.6 \mathrm{~m}$, 長さ $1.8 \mathrm{~m}$, 高さ $2.7 \mathrm{~m}$ である。空調方 式は，外気混合型 4 管式のエアハンドリングユニットを用いたダク

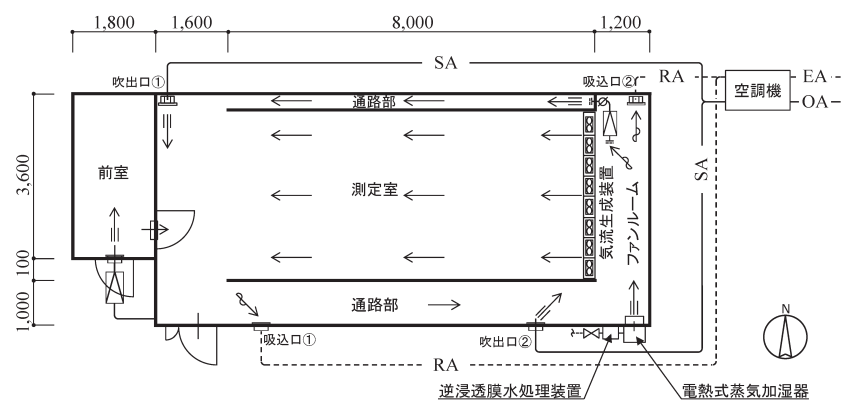

図 1 通風型人工気候室の概要

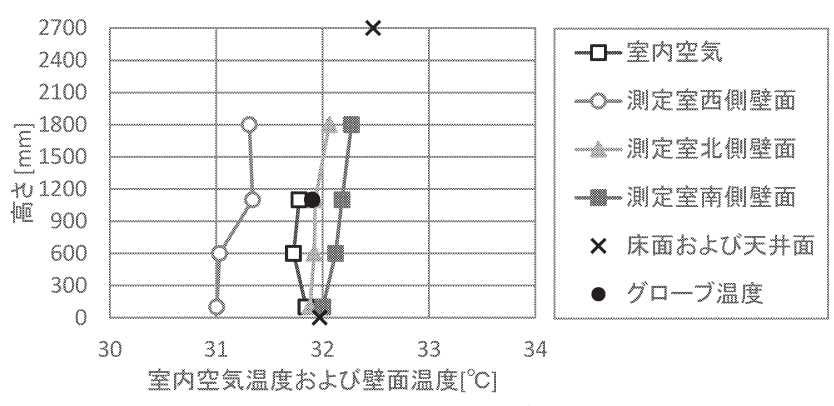

図 2 室内空気と壁面と床面および天井面の温度分布

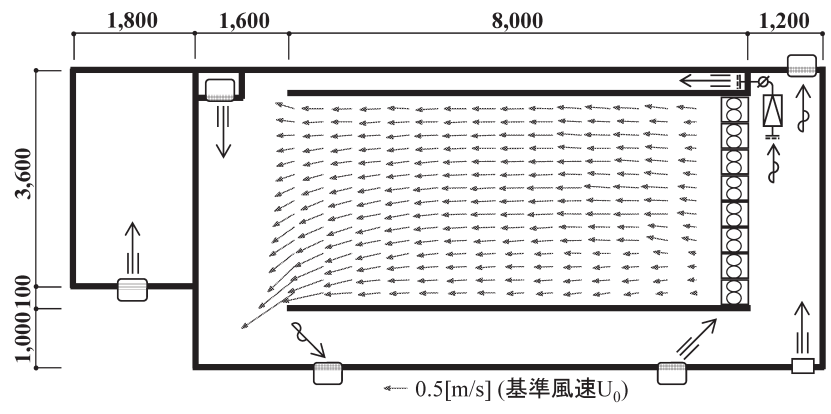

図 3 測定室における水平面風速ベクトル分布

表 1 測定機器

\begin{tabular}{|c|c|c|c|c|c|}
\hline \multicolumn{2}{|r|}{ 測定項目 } & 測定機器 & 型番 & メーカー & 測定間隔 \\
\hline 人 & 発汗量 & 発汗計 & SKN-2000 & スキノス & 1 1秒 \\
\hline 体 & 代謝量 & 代謝量計 & AT-1100 & アニマ & 実験前後5分間 \\
\hline 生 & 体重 & マルチ台科 & IS150IGC-H & ザルトリウス & 1秒 \\
\hline 理 & 皮膚温 & 熱電対 & $9201 \mathrm{~A}$ & 江藤電気 & 2秒 \\
\hline 量 & 耳内温度 & 耳内温度計 & DBTLWL-1 & テクノサイエンス & 10 秒 \\
\hline $\begin{array}{l}\text { 室 } \\
\text { 内 }\end{array}$ & $\begin{array}{c}\text { 室内温度 } \\
\text { 湿度 }\end{array}$ & 温湿度計 & RTR-57 & $T \& D$ & 1分 \\
\hline 物 & 壁面温度 & 熱電対 & $9201 \mathrm{~A}$ & 江藤電気 & 2秒 \\
\hline 理 & 風速 & 超音波風速計 & DA-650 & カイジョウ & 0.05 秒 \\
\hline 量 & グローブ温 & グローブ球 & - & - & 2秒 \\
\hline
\end{tabular}

表 2 実験条件

\begin{tabular}{|c|c|c|c|c|c|c|c|}
\hline \multirow{3}{*}{ ケース } & \multirow{3}{*}{$\begin{array}{c}\begin{array}{c}\text { 予測平均 } \\
\text { 皮膚温 }\end{array} \\
{ }^{\circ} \mathrm{C}\end{array}$} & \multirow{3}{*}{ 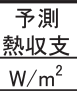 } & \multirow{3}{*}{$\begin{array}{c}\begin{array}{c}\text { 気温 } \\
(=\text { MRT })\end{array} \\
{ }^{\circ} \mathrm{C}\end{array}$} & \multirow{2}{*}{\multicolumn{2}{|c|}{$\begin{array}{l}\text { 風速 } \\
\mathrm{m} / \mathrm{s}\end{array}$}} & \multirow{3}{*}{ 相対湿度 } & \multirow{3}{*}{$\begin{array}{c}\text { 延べ } \\
\text { 被験者数 }\end{array}$} \\
\hline & & & & & & & \\
\hline & & & & フェイズ1 & フェイズ2 & & \\
\hline 1 & \multirow{3}{*}{34.0} & -10 & \multirow{3}{*}{28} & 0.1 & 0.3 & \multirow{3}{*}{70} & 4 \\
\hline 2 & & -40 & & 0.1 & 0.9 & & 7 \\
\hline 3 & & -76 & & 0.1 & 2.0 & & 6 \\
\hline 4 & \multirow{3}{*}{34.4} & -10 & \multirow{3}{*}{30} & 0.1 & 0.3 & \multirow{3}{*}{70} & 4 \\
\hline 5 & & -40 & & 0.1 & 1.3 & & 6 \\
\hline 6 & & -54 & & 0.1 & 2.0 & & 6 \\
\hline 7 & \multirow{3}{*}{35.0} & -10 & \multirow{3}{*}{32} & 0.1 & 0.4 & \multirow{3}{*}{70} & 4 \\
\hline 8 & & -24 & & 0.1 & 1.0 & & 7 \\
\hline 9 & & -40 & & 0.1 & 2.0 & & 8 \\
\hline
\end{tabular}

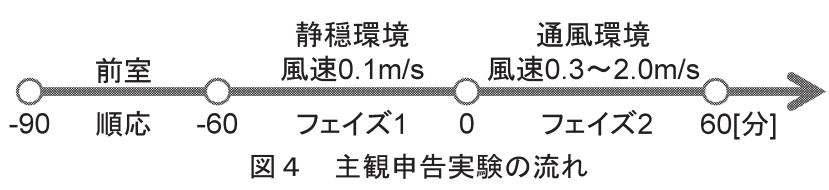


ト方式である。空調機からの吹出口は前室付近（吹出口(1)）と戻り 気流路（吹出口(2)）に配置され, 空調機からの吹き出し気流が測定 室の気温に直接影響を与えないよう配慮されている。測定室北側に ある通路状の空間は, 送風機によって測定室と同様の空気が流れて いる。また，測定室にある気流生成装置から発生した気流は測定室 南側の通路部を通り循環している。測定室南側および北側の壁面温 度は, 気流が通路部を通過することで, 測定室側の通路部壁面が概 ね気温に近い值となるように設計されている。

図 2 に室内空気と壁面と床面および天井面の温度分布を示す。環 境設定条件は, 気温 $32^{\circ} \mathrm{C}$, 相対湿度 $70 \%$, 風速 $2.0 \mathrm{~m} / \mathrm{s}$ とした。性 能試験は，主観申告実験の環境条件において気温，相対湿度および 風速が設定できる最も高い条件で行った。室内空気は測定室中央か ら $900 \mathrm{~mm}$ 風上の位置で測定した。室内空気の平均值は $31.8^{\circ} \mathrm{C}$ であ った。測定室西側壁面温度の平均值は $31.2^{\circ} \mathrm{C}$ で, 他の壁面温度およ び空気温度に比べて約 $0.8^{\circ} \mathrm{C}$ 低かった。これは, 主に前室の環境温 度が低かったことが原因であると考えられる。各壁面における高さ 方向の壁面温度差は $0.6^{\circ} \mathrm{C}$ 以内であった。壁面温度全測定点の平均 值は $31.8^{\circ} \mathrm{C}$ で, 室内空気温度の平均值との差は $0.1^{\circ} \mathrm{C}$ 以下であった。

気流生成装置は，ファンの急加速・急減速が可能な $400 \mathrm{~W}$ の $\mathrm{AC}$ モータで駆動する小型ファン 48 台で構成されている。風速は室内気 流を想定して $0.1 \mathrm{~m} / \mathrm{s}$ から $2.7 \mathrm{~m} / \mathrm{s}$ で制御可能である。測定室の断面積 である幅 $3.7 \mathrm{~m}$, 高さ $2.7 \mathrm{~m}$ の全面から気流が生成できるので, 被験 者の全身に，気流を一様に曝露することが可能となっている。図 3 に水平面の風速ベクトル分布を示す。設定した基準風速 $\mathrm{U}_{0}$ は $0.5 \mathrm{~m} / \mathrm{s}$ である。気流生成装置から $2.0 \mathrm{~m}$ 以上風下側では, 主風向に対して 直交方向 15 点の風速の平均值は, 設定風速 $0.5 \mathrm{~m} / \mathrm{s}$ との差が $0.1 \mathrm{~m} / \mathrm{s}$ 以下であった。気流生成装置から風下一 $5.5 \mathrm{~m}$ 以上離れると, 戻り 気流路への縮流により, 設定風速との差が $0.2 \mathrm{~m} / \mathrm{s}$ 以上となった。し たがって, 被験者は, 気流生成装置から風下 $2.0 \mathrm{~m}$ から $5.5 \mathrm{~m}$ の範囲 に配置することにした。

\section{2 測定機器の概要}

表 1 に測定機器を示す。気温および相対湿度の測定は, 高さ 100 , $600,1100 \mathrm{~mm}$ で測定し, 解析には 3 点の平均值を用いた。気流の測 定は，気流生成装置から $2100 \mathrm{~mm}$ 風下，床上 $1100 \mathrm{~mm}$ の位置におい て超音波三次元風向風速計で計測した。測定機器が被験者への気流 を妨げないように被験者正面から $500 \mathrm{~mm}$ 横の位置に設置した。平 均放射温度は, 天井 3 点, 壁 12 点および床面 3 点に設置した熱電対 18 点の平均值とした。

代謝量は椅子座安静状態で順応後の測定室において, 呼気ガス分 析計を用いて, 実験開始前 5 分間と実験終了後 5 分間で測定した。 皮膚温は平均皮膚温 $\theta_{s k}$ を算出するため, 面積重み付け 10 点法 ${ }^{19}$ に 対応する右半身の部位(前額, 胸上部, 胸下部, 背上部, 背下部, 上 腕，前腕，手甲，大腿，す祮)に熱電対を装着して測定した。皮膚表 面一の熱電対の貼り付けは, 気流の影響を妨げないようなメッシュ 形状のサジカルテープを用いた。面積重み付け平均による平均皮膚 温の算出式を次式(1)に示す。

$$
\begin{aligned}
\theta_{s k}= & 0.07 \times \text { 前額 }+0.35 \times \frac{(\text { 胸上部 }+ \text { 胸下部 }+ \text { 背上部 }+ \text { 背下部 })}{4}+0.07 \times \text { 上腕 } \\
& +0.07 \times \text { 前腕 }+0.05 \times \text { 手の甲 }+0.19 \times \text { 大腿 }+0.20 \times \text { す水 }
\end{aligned}
$$

\begin{tabular}{|c|c|c|c|c|c|c|}
\hline 被験者 & 性別 & 年齢 & 身長 $[\mathrm{m}]$ & 体重 $[\mathrm{kg}]$ & 体表面積 $\left[\mathrm{m}^{2}\right]$ & BMI指数 $\left[\mathrm{kg} / \mathrm{m}^{2}\right]$ \\
\hline $\mathrm{A}$ & \multirow{4}{*}{ 男性 } & 22 & 1.67 & 67 & 1.70 & 24.0 \\
\hline$B$ & & 21 & 1.73 & 60 & 1.65 & 20.2 \\
\hline C & & 22 & 1.72 & 76 & 1.83 & 25.7 \\
\hline D & & 21 & 1.71 & 58 & 1.62 & 19.8 \\
\hline $\begin{array}{l}\text { 非常に } \\
\text { 寒い }\end{array}$ & & 中立 & & 常に 暑い & 常に & $\begin{array}{l}\text { 非常に } \\
\text { 暖かい }\end{array}$ \\
\hline$-3 \quad-2$ & -1 & 0 & 2 & 3 & -2 & 2 \\
\hline
\end{tabular}

表 3 被験者の特性

(1) 寒暑感

（2）涼暖感

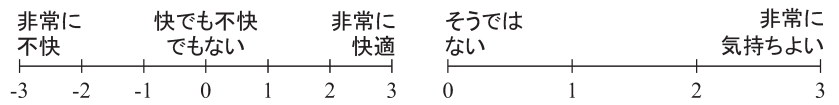

（3）快適感

図 5 主観申告スケール

（4）気持ちよさ感

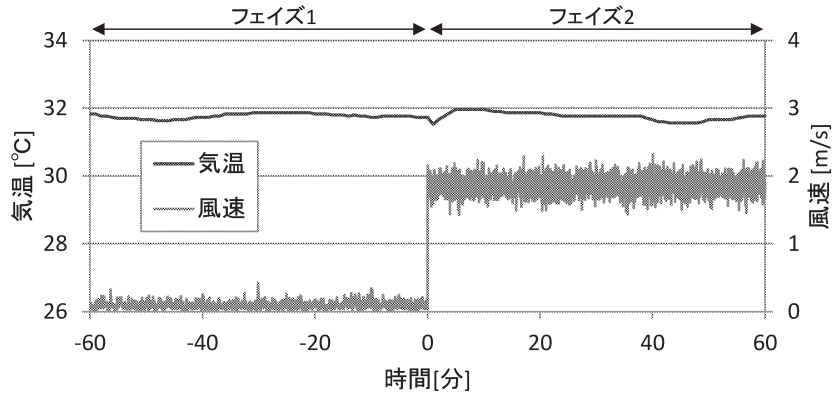

図 6 ケース 9 における気温と風速の時刻歴波形

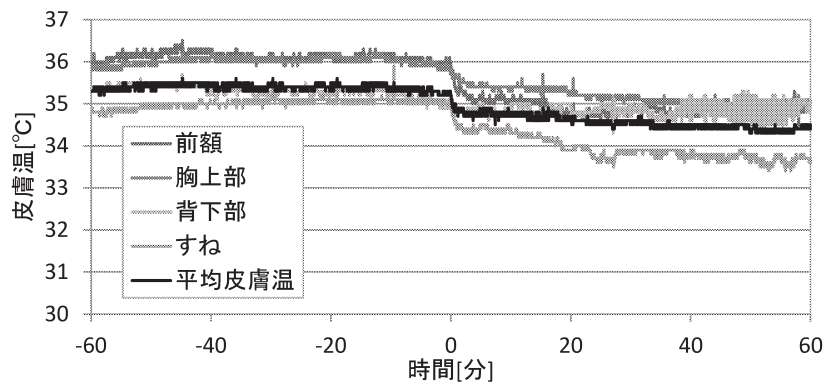

図 7 ケース 9 における部位別皮膚温の時刻歴波形

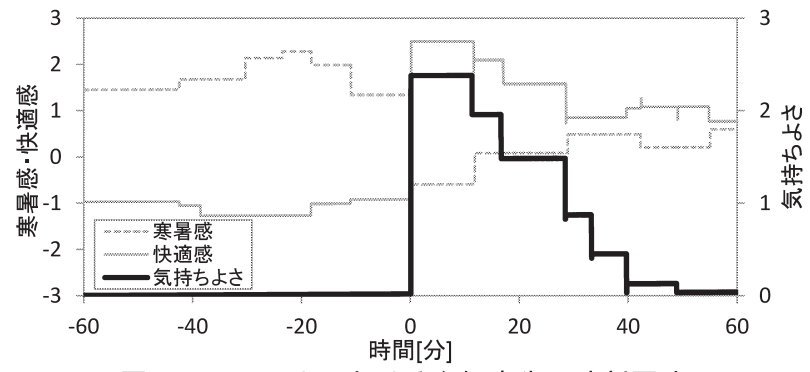

図 8 ケース 9 における主観申告の時刻歴波形

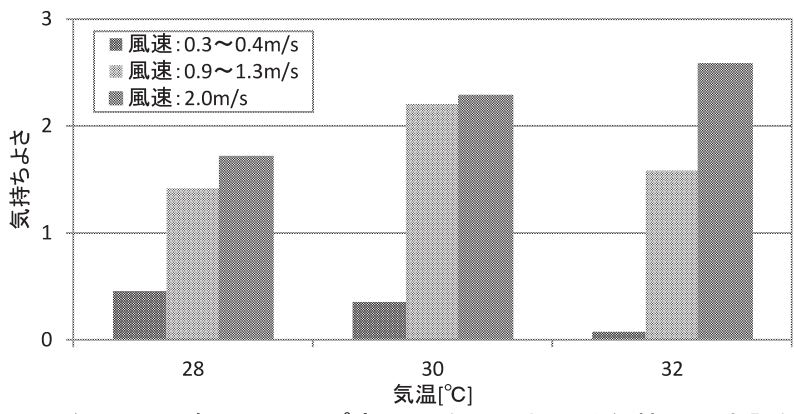

図 9 気温と風速のステップ変化の違いにおける気持ちよさ評価 の比較 


\section{5．風速をステップ変化させた場合の主観申告実験}

\section{1 主観申告実験の概要}

通風環境における気持ちよさ評価モデルについて検討するために 主観申告実験を行った。表 2 に実験条件を示す。空を開けた瞬間や, ステップ的な自然通風の変動が生じたときを想定して, 風速がステ ップ的に変化した場合における主観申告評価を測定した。飯野ら ${ }^{20)}$ の研究において通風時に「涼しい」の評価が得られた環境条件は, 気温は約 $28^{\circ} \mathrm{C} \sim 32^{\circ} \mathrm{C}$, 相対湿度は約 $55 \% \sim 80 \%$ および風速は約 $0.1 \mathrm{~m} / \mathrm{s} \sim 1.0 \mathrm{~m} / \mathrm{s}$ と報告している。実験室の温湿度条件は夏季を想定 し，風速の影響を検討するために $2.0 \mathrm{~m} / \mathrm{s}$ の条件を追加した。表 2 の 右欄に延べ被験者数を示す。各フェイズの実験条件は, 人体温熱生

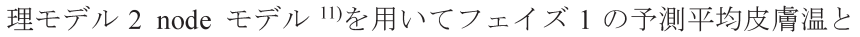
風速のステップ変化により生じる予測熱収支から決定した。図 4 に 被験者実験の流れを示す。測定開始 30 分前に前室に入り, 被験者を 測定室の環境に順応させた。6 0 分間風速 $0.1 \mathrm{~m} / \mathrm{s}$ に設定した静穏環境 で測定した後，風速を $0.3 \mathrm{~m} / \mathrm{s} \sim 2.0 \mathrm{~m} / \mathrm{s}$ にステップ的に変化させて通 風環境で 60 分間測定した。すべてのケースにおける延心゙被験者数は 52 であった。

被験者の姿勢は，住宅における休息時を想定して，代謝率が 1 met 程度の椅子座安静とした。着衣量は，気流が人体に及ぼす影響を妨 げないように, トランクスのみとして, 限りなく裸に近い条件とし た。実験は季節順応を考慮して 2012 年 6 月から 9 月の夏季に行った。 表 3 に被験者の特性を示す。多くの既往研究 ${ }^{21), 22)}$ において年齢や 性別による温熱快適性一及ぼす影響が検討されている。本研究では 月経による温熱的生理量に変動がある女性を除き，定性的な傾向を 捉えることを目的として, 標準的な体格である健常な男子大学生 4 名と した。人体の体表面積の算出には, 日本人の体型を考慮した藤本ら 23)の算出式を用いた。

図 5 に主観申告スケールを示す。ASHRAE ${ }^{10}$ および空気調和・衛 生工学会 ${ }^{199}$ が提案する 7 段階スケールを参考にして, 寒暑感・涼暖 感・快適感は 7 段階, 気持ちよさは 4 段階を目安に無段階で評価し た。気持ちよさは, Gagge ら ${ }^{16)}$ が提案する消極的快適性における「不 快」との混同した申告を避け, 評価対象を明確にするために, 気持 ちよい側のみとした。主観申告は主観申告装置のレバーを被験者に 任意の時間に操作してもらい, サンプリング間隔 1 秒で記録した。 申告值は電圧で出力され，データロガーを用いて集録した。

\section{2 被験者実験の結果および考察}

図 6 にケース 9 における気温と風速の時刻歴波形を示す。実験条 件は気温 $32^{\circ} \mathrm{C}$, 風速 $0.1 \mathrm{~m} / \mathrm{s}$ から $2.0 \mathrm{~m} / \mathrm{s}$ へのステップ変化である。 気温の 120 分間平均值は $31.8^{\circ} \mathrm{C}$, 標準偏差は $0.1{ }^{\circ} \mathrm{C}$ で, 概衩一定に 保たれていた。風速の各フェイズ 60 分間平均值は, フェイズ 1 が $0.10 \mathrm{~m} / \mathrm{s}$ で,フェイズ 2 が $1.85 \mathrm{~m} / \mathrm{s}$ であった。風速の各フェイズの標準偏差はフェイ ズ 1 が $0.05 \mathrm{~m} / \mathrm{s}$ で, フェイズ 2 が $0.12 \mathrm{~m} / \mathrm{s}$ であった。風速のステップ変化 の実験条件を概敉作成できた。

図 7 にケース 9 における部位別皮膚温の時刻歴波形を示す。デー 夕は被験者 1 名の例である。フェイズ 1 の静皧環境における平均皮 膚温は 2 node モデルで算出された $35^{\circ} \mathrm{C}$ よりも $0.4^{\circ} \mathrm{C}$ 程度高い值を 示した。フェイズ 2 の通風環境における平均皮膚温は風速のステッ プ変化直後に急激に低下した後, 緩やかに低下寸る傾向を示した。 前額，すねの温度は風速のステップ変化によって時間の経過ととも

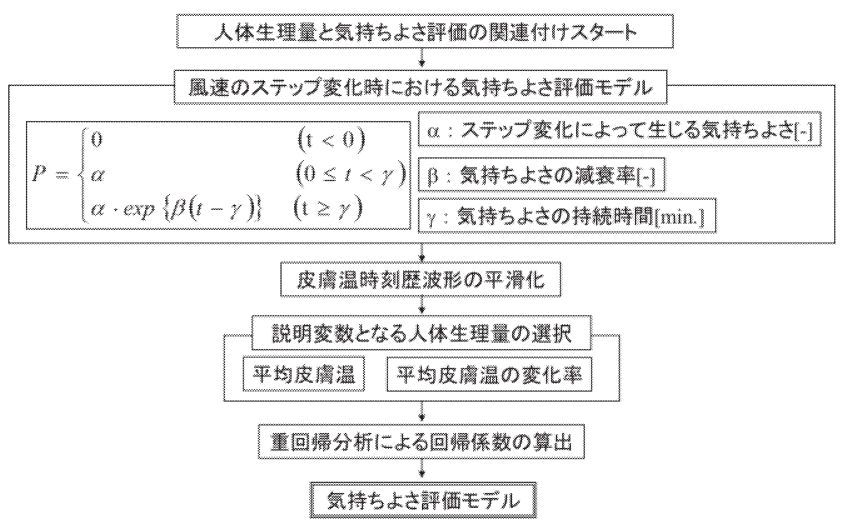

図 10 気持ちよさ評価モデル算出の流れ

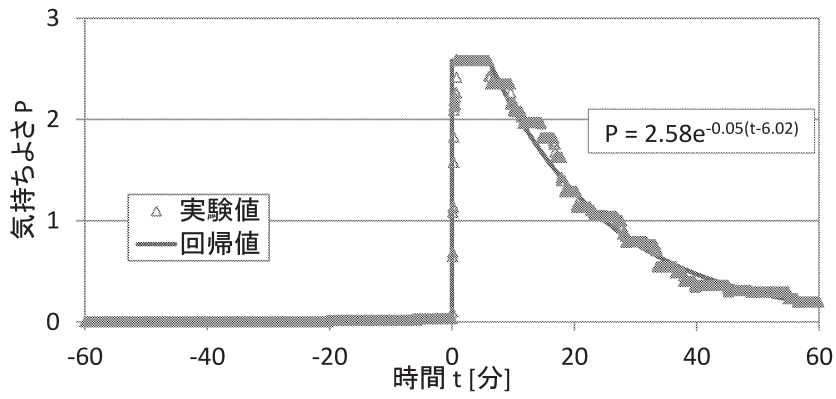

図 11 ケース 9 における気持ちよさの時刻歴波形と近似曲線

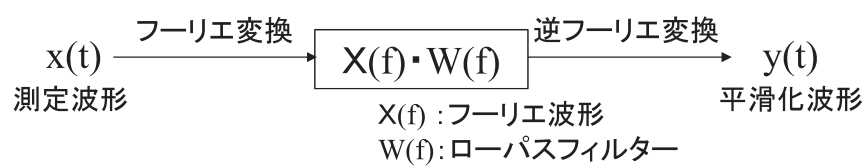

図 12 フーリエ変換を用いた皮膚温データの平滑化の流れ

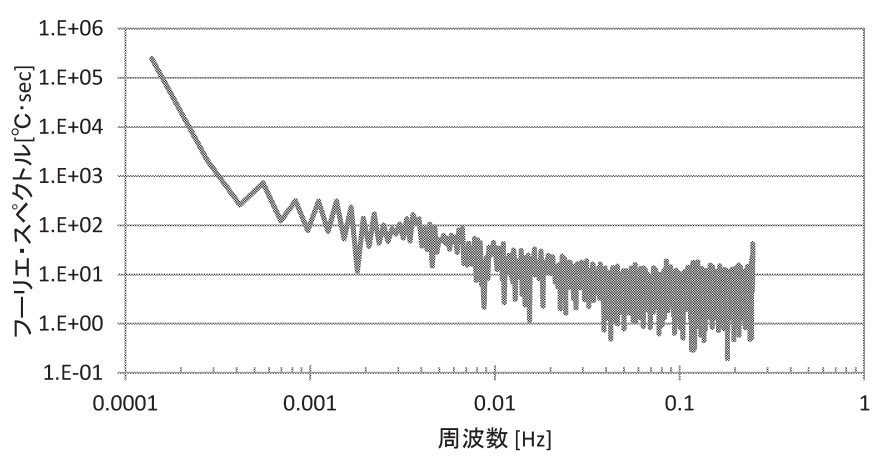

図 13 ケース 9 における平均皮膚温のフーリェ·スペクトル分布

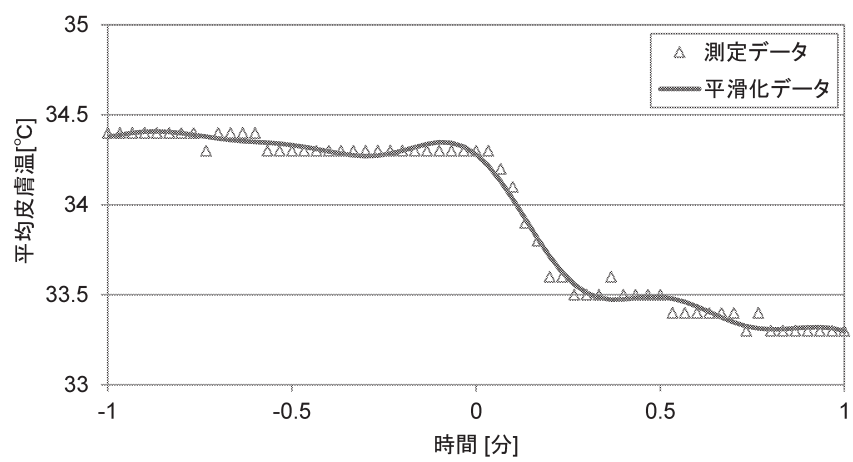

図 14 ケース 9 における平滑化した平均皮膚温の時刻歴波形 
に低下した。背下部の温度は他の部位に比べて低下しなかった。背 下部は被験者の風下側に位置していたため, 風速の影響が小さかっ たことが考えられる。

図 8 にケース 9 における主観申告の時刻歴波形を示す。データは 被験者 1 名の例である。フェイズ 1 の静穏環境では, 寒暑感は「暑 い, 快適感は「やや不快」で概ね一定であった。静穏環境において 気持ちよさは生じなかった。フェイズ 2 の通風環境では，気持ちよ さはステップ変化直後において最大值となった。フェイズ 2 の気持 ちよさは時間の経過とともに低下し, ステップ変化から 60 分経過後 では「そうではない」となった。したがって，通風環境の気持ちよ さは一過性の心理量であるといえる。気持ちよさが最も高かった時 間の寒暑感と快適感は, 60 分後の寒暑感と快適感に比べて, より「寒 い」側および「快適」側に申告していた。気持ちよさによって快適 感が増加したと考えられる。

一般的な温冷感指標である PMV や SET*は長時間経過後の定常状 態を対象とした指標であることから, 本研究で観測された通風環境 の気持ちよさを評価することは困難であることが推察できる。

図 9 に気温と風速のステップ変化の違いによる気持ちよさ評価を 示す。風速のステップ変化が $0.3 \sim 0.4 \mathrm{~m} / \mathrm{s}$ の場合, ステップ変化直後 の気持ちよさは，気温が低いほど大きな值を示した。風速のステッ プ変化が $0.9 \sim 1.3 \mathrm{~m} / \mathrm{s}$ の場合, 気持ちよさは気温が $30^{\circ} \mathrm{C}$ のときに大 きな值を示した。風速のステップ変化が $2.0 \mathrm{~m} / \mathrm{s}$ の場合, ステップ変 化直後の気持ちよさは，気温が高いほど大きな值を示した。ステッ プ変化直後の気持ちよさは, 気温と風速の組み合わせによって変化 すると予想される。

\section{6. 気持ちよさ評価モデルの検討}

\section{1 気持ちよさ評価の実験回帰モデル}

図 10 に気持ちよさ評価モデル算出の流れを示す。気持ちよさと 人体生理量の関連付けは重回帰分析により検討した。気持ちよさは 一過性の心理量であることから, 気持ちよさの実験回帰モデルを式 (2)で表した。

$$
P= \begin{cases}0 & (\mathrm{t}<0) \\ \alpha & (0 \leq t<\gamma) \\ \alpha \cdot \exp \{\beta(t-\gamma)\} & (\mathrm{t} \geq \gamma)\end{cases}
$$

気持ちよさ $\mathrm{P}$ は一定時間持続する傾向を示したため, 持続時間を 考慮した。 $\alpha$ はステップ変化によって生じる気持ちよさ, $\beta$ はステ ップ変化によって生じた気持ちよさの減衰率, $\gamma$ は気持ちよさの持 続時間である。t はステップ変化からの経過時間である。図 11 に ケース 9 における全被験者の気持ちよさの時刻歴波形と近似曲線を 示す。データはケース 9 における全被験者のアンサンブル平均值で ある。ケース 9 における $\alpha$ は $2.58, \beta$ は一 $0.05, \gamma$ は 6 分であった。 定常状態では $\mathrm{t}$ が無限大であるといえるため, 定常状態の気持ちよ さは $\alpha, \beta, \gamma$ にらず 0 となる。

\section{2 重回帰分析による気持ちよさ評価モデルの検討}

気持ちよさ評価モデルを人体生理量と関連付けるために, $\alpha, \beta, \gamma$ を目的変数として重回帰分析を行い, 気持ちよさ評価モデルを導出 した。重回帰分析に用いるパラメータは, 実験で測定した人体生理 量と気持ちよさの時刻歴波形から読夕取った。皮膚温と発汗量との

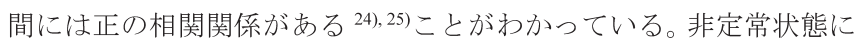

おける温冷感予測に関する既往研究 ${ }^{26,27)}$ を参考に, $\alpha, \beta, \gamma$ の説明変 数には平均皮膚温と平均皮膚温の変化率を採用した。平均皮膚温の 変化率が負のときに, 人体の深部温度と平均皮膚温のかい離を表現 している。したがって，深部温度は気持ちよさ評価モデルの説明変 数から除いた。また，他の人体生理量である血流量やふるるえによる 熱生産は，平均皮膚温との相関関係を持ち，重回帰分析においては 多重共線性 ${ }^{28)}$ のおそれがあるので説明変数から除外した。

\section{3 周波数領域法による皮膚温時刻歴波形の平滑化}

皮膚温データの雑音を除去するために, 周波数領域法を用いて皮膚 温時刻歴波形の平滑化を行った。図12にフーリエ変換を用いた皮膚温 データの平滑化の流れを示す。測定波形を高速フーリエ変換した後, フ イルタ関数を乗じて, 逆フーリエ変換することで平滑化波形を得た。

図13に平均皮膚温のフーリエ・スペクトル分布を示寸。カットオフ周波 数はスペクトル分布から $0.04 \mathrm{~Hz}$ とし, $0.04 \mathrm{~Hz}$ 以上のスペクトルは 0 となる ようなローパスフィルタ関数とした。図14に平均皮膚温の平滑化を示す。

\section{表 4 全ヶースにおける気持ちよさの近似曲線の回帰係数}

\begin{tabular}{c|c|c|c|c|c}
\hline ケース & $\theta_{\text {sk }}$ & $\Delta \theta_{\text {sk }} / \Delta \mathrm{t}$ & $\alpha$ & $\beta$ & $\gamma$ \\
\hline \hline 1 & 33.8 & -0.01 & 0.5 & -0.03 & 0.0 \\
\hline 2 & 33.6 & -0.04 & 1.4 & -0.02 & 7.2 \\
\hline 3 & 33.6 & -0.07 & 1.7 & -0.06 & 4.5 \\
\hline 4 & 34.2 & 0.00 & 0.4 & -0.02 & 0.0 \\
\hline 5 & 34.0 & -0.04 & 2.2 & -0.04 & 9.0 \\
\hline 6 & 34.2 & -0.06 & 2.3 & -0.06 & 6.3 \\
\hline 7 & 34.6 & -0.02 & 0.1 & 0.00 & 0.0 \\
\hline 8 & 34.6 & -0.05 & 1.6 & -0.04 & 7.0 \\
\hline 9 & 34.5 & -0.08 & 2.6 & -0.05 & 6.0 \\
\hline \hline 平均値 & 34.1 & -0.04 & 1.4 & 0.0 & 4.4 \\
\hline 標準偏差 & 0.4 & 0.03 & 0.9 & 0.0 & 3.5 \\
\hline
\end{tabular}

表 5 偏回帰係数の有意検定の結果

\begin{tabular}{c|c|c}
\hline 目的変数 & $\theta_{\mathrm{sk}}{ }^{*}$ & $\Delta \theta_{\mathrm{sk}}{ }^{*} / \Delta \mathrm{t}^{*}$ \\
\hline \hline$\alpha^{*}$ & - & $1 \%$ \\
\hline$\beta^{*}$ & - & $1 \%$ \\
\hline$\gamma^{*}$ & - & $5 \%$ \\
\hline
\end{tabular}

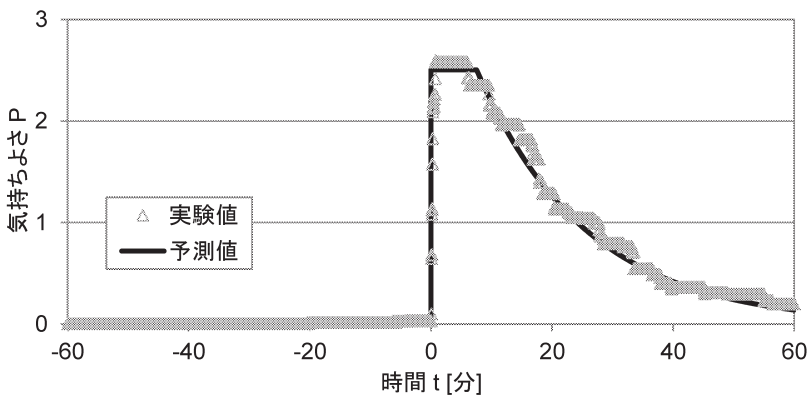

図 15 ケース 9 における気持ちよさの時刻歴波形の精度検証

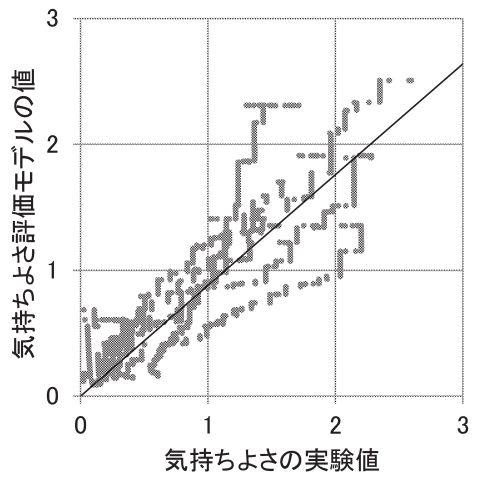

図 16 全ケースにおける気持ちよさ評価モデルの精度検証 
平均皮膚温の高周波数の変動が平滑化された。平滑化された平均皮膚 温の時刻歴波形から, 気持ちよさの説明変数に用いるステップ変化時の 平均皮膚温と平均皮膚温の変化率を算出した。熱的刺激の時間が 3 秒 を越えると温度感覚の違いは小さくなると報告されているので ${ }^{29)}$, 平均皮 膚温の変化率の算出に用いる $\Delta \mathrm{t}$ は 4 秒とした。

\section{4 気持ちよさ評価モデルの重回帰分析結果}

表 4 に全ケースにおける気持ちよさの近似曲線の回帰係数を示す。 データはケースごとにおける全被験者の平均值である。重回帰分析 から得られた結果を式(3)から式(5)に示す。

$$
\begin{aligned}
& \alpha^{*}=0.01 \theta_{s k}^{*}-0.87 \frac{\Delta \theta_{s k}^{*}}{\Delta t^{*}} \\
& \beta^{*}=0.12 \theta_{s k}^{*}+0.79 \frac{\Delta \theta_{s k}^{*}}{\Delta t^{*}} \\
& \gamma^{*}=-0.07 \theta_{s k}^{*}-0.69 \frac{\Delta \theta_{s k}^{*}}{\Delta t^{*}}
\end{aligned}
$$

$\alpha^{*}, \beta^{*}, \gamma^{*}, \theta \mathrm{sk}^{*}, \Delta \theta \mathrm{sk}^{*} / \Delta \mathrm{t}^{*}$ は，基準化したパラメータである。パラ メータは, 平均值を差し引き, 標準偏差で除すことで基準化した。 重相関係数は $\alpha^{*}$ が $0.87, \beta^{*}$ が $0.80, \gamma^{*}$ が 0.69 だった。

表 5 に偏回帰係数の有意検定の結果を示す。有意検定において, $\alpha *$ に対する平均皮膚温の変化率と $\beta^{*}$ に対する平均皮膚温の変化率 $\Delta \theta \mathrm{sk} * / \Delta \mathrm{t}^{*}$ が $1 \%$ 未満で， $\gamma^{*}$ に対する平均皮膚温の変化率 $\Delta \theta \mathrm{sk}^{*} / \Delta \mathrm{t}^{*}$ が $5 \%$ 未満での有意性が得られた。平均皮膚温は寸べてのパラメータに おいて $5 \%$ の有意水準を得られなかった。これは全ケースのフェイズ 1 の環境条件が「中立」から「やや暑い」環境条件であったことが 原因であると考えられる。自然通風の評価のためには, 実験条件お よびサンプル数の増加や有意性のある説明変数の選択が必要である。

式(3)は, 久野ら ${ }^{177}$ によプレザントネスの概念と同様の傾向を示 し，体が熱く不快な状態のときに「中立」および「やや寒い」環境 へのステップ変化が気持ちよいと感じる予測式となっている。ただ し，暑熱環境における急激な環境変化は人体一の熱的衝撃が大きい ため, 本予測式は表 2 に示寸「通風の涼しさ」が起こり得る実験条 件の範囲内で適用される。

\section{7. 気持ちよさ評価モデルの予測精度}

重回帰分析から得られた気持ちよさ評価モデルと実験の生理量デ 一タを用いて気持ちよさの予測精度を検証した。図 15 にケース 9 における気持ちよさの時刻歴波形の精度検証を示す。ステップ変化 によって生じる気持ちよさ, 気持ちよさの持続時間および気持ちよさの 減衰を概ね再現できた。精度検証には次の式(6)から算出される誤差の 標準偏差 RMS を用いた。RMS は 0.08 であった。

$$
R M S=\sqrt{\frac{1}{n} \sum_{i=1}^{n}\left(P_{p r, i}-P_{e x, i}\right)^{2}}
$$

図 16 に気持ちよさ評価モデルの精度検証を示す。データは, 全 ケースにおけるフェイズ 2 の 32,409 個である。風速が静穏環境から 通風環境へステップ的に変化した場合において, 気持ちよさ評価モ デルによる予測值と実験值における誤差の標準偏差 RMS は 0.30 で あった。気持ちよさが高い場合に, 予測誤差が大きくなったのは, $\alpha^{*}, \beta^{*}$, $\gamma^{*}$ の予測式を一次式としたことおよび平均皮膚温の有意性が低かったこ とが原因であると考えられる。

\section{8. 結語}

人体の過渡的な主観申告を調査するために, 通風型人工気候室を用 いて, 風速がステップ的に変化する通風環境における主観申告実験を 行った。既往研究から通風時に「涼しい」の評価が得られた環境条件を 実験条件に含めた ${ }^{20)}$

通風環境における気持ちよさ評価と人体の生理量を関連付けた気持 ちよさ評価モデルについて検討し，次の知見が得られた。

（1）通風環境の気持ちよさの経時変化は, 寒暑感・快適感とは異なり, 一過性の傾向があることを明らかにした。気持ちよさは不快な状態 から急激に環境が変化することで発生することが原因と考えられる。

(2) 快適感は風速のステップ変化直後の気持ちよさが生じている間で, 快適側に申告される傾向を示した。

（3）一般的な温冷感指標である PMV やSET*は長時間経過後の定常 状態を対象とした指標であることから, 本研究で観測された通風環 境の気持ちよさを評価することは困難であることがわかった。

（4）風速のステップ変化直後における気持ちよさは, 気温と風速のステ ップ変化量との組み合わせによって変化することがわかった。

（5）風速が静穏環境から通風環境へステップ的に変化した場合におい て, 平均皮膚温の変化率は気持ちよさ評価に与える影響が大きい ことが判った。

今後, 実験条件を増やし, 気持ちよさの実験回帰モデルをさらに検討 し, 予測精度を向上させることが必要である。また, 通風時の気持ちよさ 評価に及ぼす年齢や性別の影響を調査する必要がある。

\section{謝辞}

本研究は, 文部科学省グローバル COE プログラム「風工学・教育研究 のニューフロンティア」(拠点リーダー: 田村幸雄 (当時))ならびに独立行 政法人日本学術振興会奨励費(11222)の助成を受けました。東京工芸大 学大場正昭研究室, 東京理科大学倉烪隆研究室および関東学院大学 遠藤智行研究室による合同通風研究打ち合わせ会を通じて, 多大なる ご助言とご指導を頂きました。通風型人工気候室を用いた被験者実験で は東京工芸大学水谷国男教授ならびに塚本健二研究員のご協力を得 ました。また, ご協力いただいた被験者の方々に感謝の意を表します。

記号

$\gamma$

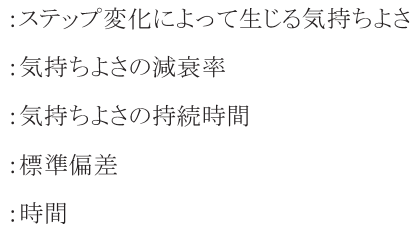




$$
\beta^{*}=\frac{\beta-\bar{\beta}}{\sigma}
$$

$\gamma^{*}$

$$
\text { : 基準化した気持ちよさの持続時間 }
$$

$$
\gamma^{*}=\frac{\gamma-\bar{\gamma}}{\sigma}
$$

$\Delta \theta_{\mathrm{sk}} * / \Delta \mathrm{t} *$ : 基準化した平均皮膚温の変化率

$$
\frac{\Delta \theta_{s k} *}{\Delta t^{*}}=\frac{\frac{\Delta \theta_{s k}}{\Delta t}-\overline{\left(\frac{\Delta \theta_{s k}}{\Delta t}\right)}}{\sigma}
$$

\section{本論文に関連する既発表論文}

*1) 大場正昭, 森上伸也, 通風環境における温熱生理 2 node モデルの不感蒸泄 に関する検討, 日本建築学会大会学術講演会梗概集, 2013(環境工学 II), pp.347-348, 2013.8.

*2) 森上伸也, 大場正昭：通風環境における温熱生理 2 node モデルの拡張型 蒸発モデルに関する検討, 日本建築学会大会学術講演会梗概集, 2014(環境 工学 II), pp.359-360, 2014.9.

*3) 大場正昭, 森上伸也 : 静穏環境と通風環境における気持ちよさ評価に関す る研究：その 1 非定常静穏環境における気持ちよさの被験者実験, 日本建 築学会大会学術講演会梗概集, 2012(環境工学 II), pp.379-380, 2012.9.

*4) 森上伸也, 大場正昭, 塚本健二, 倫裕發 : 静榣環境と通風環境における気 持ちよさ評価に関する研究, その 2 非定常静稳環境における気持ちよさ予測 式の検討, 日本建築学会大会学術講演会梗概集, 2012(環境工学 II), pp.381-382, 2012.9.

*5) 森上伸也, 大場正昭 : 静穏環境と通風環境における気持ちよさ評価に関す る研究, その 3 静穏環境から通風環境へステップ変化した場合の気持ちよさの 実験回帰モデルについて，日本建築学会大会学術講演会梗概集，2013(環 境工学 II), pp.349-350, 2013.8 .

\section{参考文献}

1) 日本建築学会編：実務者のための自然換気設計ハンドブック，技報堂出 版, 2013.8 .

2) 健康維持増進住宅研究委員会, 健康維持増進住宅研究コンソーシアム 編：健康に暮らすための住まいと住まい方 エビデンス集, 技報堂出版, pp.6-7, 2013.6.

3) 田辺新一, 小林素子, 米山直子, 北川晃一, 土井隆司：浸室 - 寝床内環境 の快適性に関するアンケート調査, 空気調和・衛生工学会学術講演論文 集, pp.1253-1256, 1995.10.

4) 倉㴊隆：初学者のための建築講座 建築環境工学, 市ヶ谷出版社, pp.124-131, 2006.10.

5) 下地恒英, 大場正昭, 飯野秋成, 飯野由香利, 安中哲夫, 小寺定典 : 通風 時および空調時における温熱環境評価の実態, その 1 各気流時における 温熱環境評価の特性, 日本建築学会大会学術講演梗概集, D-2, pp.473-474, 2007.8.

6) 飯野由香利, 大場正昭, 飯野秋成, 安中哲夫, 小寺定典：通風時および 空調時における温熱環境評価の実態, その 2 気流変動と温熱環境評価と の関係, 日本建築学会大会学術講演梗概集, D-2, pp.475-476, 2007.8.

7) 赤林伸一, 佐々木淑貴, 坂口淳, 富永禎秀 : 通風性能の定量的評価手法 に関する研究，日本建築学会環境系論文集第 568 号, pp.49-56, 2003.6.

8) P.O. Fanger : Thermal Comfort, Analysis and Applications in Environmental Engineering, McGraw-Hill, New York, 1970.

9) International Standard 7730 : Analytical determination and interpretation of thermal comfort using calculation of the PMV and PPD indices and local thermal comfort criteria. ISO, Geneva.

10) ASHRAE Handbook Fundamentals, ASHRAE, Chapter 8, p.8, 2001.

11) Gagge et al., A Standard Predicted Index of Human Response to the Thermal Environment, ASHRAE Transactions, Vol.92, Part2, pp.709-731, 1986.

12) 桑沢保夫, 鎌田元康, 千田善孝：変動風の快適性に及ぼす影響に関する 研究, その 10 変動風の総合的な効果について, 日本建築学会大会学術講 演梗概集, D-2, pp.405-406, 1998.7.

13）佐藤英樹，赤林伸一，坂口淳，桑原亮一：通風時の室内における快適性
評価手法に関する基礎的研究, 日本建築学会環境系論文集第 75 巻, 第 647 号, pp.59-66, 2010.1.

14) 小野間萌，長沢俊，徳永佳代，宿谷昌則：「涼しさ」感をもたらす熱環境と人 体エクセルギー収支に関する研究, その 1 実験概要と物理量の測定結果, 日 本建築学会大会学術講演梗概集, D-2, pp.41-42, 2010.9.

15) M. Cabanac : Physiological role of pleasure, Science 173, pp. 1103-1107, 1971

16) A. P. Gagge, J. A. J. Stolwijk, B. Saltin : Comfort and thermal sensations and associated physiological responses during exercise at various ambient temperatures, Environment Research 2, pp.209-229, 1968.

17) 久野覚，大野秀夫，中原信生: 温熱環境が変化する場合を含んだ温冷感評 価について, 寒暑感と涼暖感, 日本建築学会大会学術講演梗概集, D, pp.543-544, 1985.10.

18）水谷国男，大場正昭，佐藤英樹：アクティブ制御マルティファン通風気 候風洞の風速変動特性, 第 21 回風工学シンポジウム論文集, pp.125-129, 2010.12 .

19) 空気調和・衛生工学会：新版快適な温熱環境のメカニズム 豊かな生活 空間を目指して, 丸善, 2006 .

20）飯野由香利，大場正昭，飯野秋成，安中哲夫，小寺定典：通風時と空調時 の気流環境における温熱環境評価の特性, 日本建築学会北陸支部研究報 告集第 50 号, pp.217-220, 2007.7.

21) 宮本征一：オフィス空間におけるスーツ着用時の温熱的快適域に関する研 究, その 1 冬季の低湿度条件における温泠感の性差について, 日本建築学 会環境系論文集第 620 号, pp.31-36, 2007.10.

22）都築和代，森郁恵，松本太，片岡拓也：暑熱環境における高齢者の局所冷 気流の好みに関する実験的研究，人間-生活環境系シンポジウム報告集 34 , pp.233-234, 2010.11.

23) 藤本薰喜, 渡辺孟, 坂本淳, 湯川幸一, 森本和枝 : 日本人の体表面積に関 する研究，第 18 編，三期にまとめた算出式，日衛誌 (Jap. J. Hyg.)，第 23 巻， 第 5 号, 1968.12.

24) 森上伸也, 大場正昭：気流の変動周期が人体の皮膚温、耳内温度と発汗 特性に及ぼす影響について，風工学シンポジウム論文集，日本風工学会， Vol.23, pp. 85-90, 2014.12.

25）森上伸也，大場正昭，塚本健二，倫裕撥：気流の変動周期が人体の平均 皮膚温と発汗量に及ぼす影響に関する検討，風工学シンポジウム論文集，日 本風工学会, Vol. 22, pp. 43-48, 2012.12 .

26) 高田暁，松下敬幸：非定常状態における温冷感予測式に関する研究，皮膚 温を用いた予測式の提案，日本建築学会近畿支部研究報告集，pp.289-292, 2009.5.

27）森郁恵，鉾井修一，高田暁，田中宏明：非定常状態における温冷感予測に 関寸る実験的考察，日本建築学会環境系論文集第 563 号, pp.9-15, 2003.1.

28) 久米均, 飯塚悦功：回帰分析, 岩波書店, pp.193-194, 1987.

29) Lawrence E. Marks and Joseph C. Stevens : Temporal summation related to the nature of the proximal stimulus for the warmth sense, perception and Psychology, 14, No.3, pp.570-576, 1973. 


\section{EXPERIMENTAL STUDY ON EVALUATION MODEL OF PLEASANT SENSATION UNDER THE}

CROSS-VENTILATED ENVIRONMENT

Analysis under step-wisely changing wind velocity

\section{Shinya MORIKAMI* and Masaaki OHBA**}

* Assist. Prof., Dept. of Architecture, National Institute of Technology, Toyota College, Dr.Eng.

** Emeritus Prof., Tokyo Polytechnic University, Dr.Eng.

Geographically, Japan is located in the humid subtropical Asia-Pacific region. In Tokyo, the highest temperature of August, 2014 reached $37.6{ }^{\circ} \mathrm{C}$. Traditionally, the cross-ventilation is considered to be one of the effective means for obtaining better indoor thermal comfort in Japan. The cross-ventilation can relieve the sensation of discomfort even in muggy hot summer and produce pleasant environment to the residents. It is also expected to reduce the energy consumption of indoor air conditioners. In addition, from a viewpoint of healthy life with natural environments, the effective utilization of the cross ventilation is important.

In this study, human-subjective experiments were conducted for step-wise change of wind velocity using a climate-controllable wind tunnel. The cross-ventilated environment of summer season in Japan was simulated in the test room. The airflow was step-wisely changed while keeping air temperature and humidity constant. The subjects wore trunks and stayed in a sedentary position during the experiment.

In the experiments, the time history of pleasant sensation showed the different transient tendency with the cold-hot and thermal comfort sensation. While pleasantness was occurring, the thermal comfort sensation moved to a more comfortable level. It was found that the pleasant sensation under step-wisely changing wind velocity varied with a combination of air temperature and wind velocity.

It was also found that PMV and SET* cannot evaluate thermal comfort of cross-ventilated environment for unsteady state, because these were general thermal sensation indexes for steady state.

From the experiment data, the pleasant sensation was approximated in expression (2). The phenomenon that the pleasantness decreases in the process of time was approximated by an exponential function. The pleasant sensation in the cross-ventilated environment when wind velocity step-wisely changed could be predicted by the accuracy within RMS (Root Mean Square) of 0.30 . It was also found that the change rate of mean skin temperature had a significant influence on evaluation of pleasant sensation. 